\title{
The Structural Performance Analysis of Base-Isolated Hospital Buildings with Analysis Modal (Case Study: General Hospital in Labuhan Batu Utara Regency Area)
}

\author{
Muhammad Irwansyah, Johannes Tarigan, and Zulfazly Putra \\ Civil Engineering Department, Faculty of Engineering, Universitas Sumatera Utara
}

\begin{abstract}
The development of earthquake analysis towards structures is required to prevent damages and loss in buildings due to earthquakes. The base isolation system is a simple design approach for earthquake-resistant buildings to protect the structures and components from the risk of earthquake damages by using the concept of reducing earthquake forces. This research aims to analyze the performance of a general hospital building in Labura Regency area in order to know the safety of the building in terms of period, frequency, base shear force, displacement and earthquake force, used the base isolators and without the base isolators. The method used is response-spectrum dynamic analysis by ETABS v2016 program. From the calculation of structural analysis, the application of base isolation is able to build up the period of the structure, therefore, the maximum acceleration of earthquakes can be reduced at certain period. There is an average increase by $48.21 \%$ of the structural period compared to non-isolated base structure, and the frequency that occurs in structures using base isolators is smaller than without base isolators. The friction force obtained is smaller compared to the structures without dampers. Base-isolated building structures observed have bigger displacement than non-base isolated structures. The average rise of the building displacement is $27.14 \%$ at $\mathrm{x}$ and $2.74 \%$ at $\mathrm{y}$ directions. In base-isolated structures, earthquake forces are reduced averagely by $57.51 \%$ at $\mathrm{x}$ and $82.73 \%$ at $\mathrm{y}$ directions. The analysis of structural performance, General Hospital in Labura Regency is categorized to Immediate Occupancy (IO) in which the building structures are safe with no significant risk of fatalities due to structural failures, there are no any significant damages and the building can be used and functioned/operated again immediately.
\end{abstract}

Keywords: Response-spectrum, base isolation, lead rubber bearing, structural performance level

Abstrak. Pengembangan analisis gempa terhadap struktur diperlukan untuk mencegah
kerusakan dan kehilangan pada bangunan karena gempa bumi. Sistem isolasi dasar
adalah pendekatan desain sederhana untuk bangunan tahan gempa untuk melindungi
struktur dan komponen dari risiko kerusakan gempa dengan menggunakan konsep
pengurangan kekuatan gempa. Penelitian ini bertujuan untuk menganalisis kinerja
bangunan rumah sakit umum di wilayah Kabupaten Labura untuk mengetahui
keamanan bangunan dalam hal periode, frekuensi, gaya geser dasar, gaya geser dan
gempa, menggunakan isolator dasar dan tanpa isolator dasar. Metode yang digunakan
adalah analisis dinamik respons-spektrum oleh program ETABS v2016. Dari

*Corresponding author at: Civil Engineering Department, Faculty of Engineering, Universitas Sumatera Utara, Medan 20155

E-mail address: Johannes.tarigan@usu.ac.id

Copyright (C) 2019 Published by Talenta Publisher, p-ISSN: 2656-1476, e-ISSN: 2655-8599

Journal Homepage: https://talenta.usu.ac.id/index.php/jet 
perhitungan analisis struktural, penerapan isolasi dasar mampu membangun periode struktur, oleh karena itu, percepatan maksimum gempa bumi dapat dikurangi pada periode tertentu. Ada peningkatan rata-rata sebesar $48,21 \%$ dari periode struktural dibandingkan dengan struktur dasar non-terisolasi, dan frekuensi yang terjadi pada struktur menggunakan isolator basis lebih kecil daripada tanpa isolator dasar. Gaya gesekan yang diperoleh lebih kecil dibandingkan dengan struktur tanpa peredam. Struktur bangunan yang diisolasi dari dasar yang diamati memiliki perpindahan yang lebih besar daripada struktur yang tidak diisolasi dari dasar. Rata-rata kenaikan perpindahan bangunan adalah 27,14\% pada arah $x$ dan 2,74\% pada arah y. Dalam struktur basis-terisolasi, gaya gempa berkurang rata-rata sebesar 57,51\% pada arah $x$ dan $82,73 \%$ pada arah y. Analisis kinerja struktural, Rumah Sakit Umum di Kabupaten Labura dikategorikan sebagai Immediate Occupancy (IO) di mana struktur bangunan aman tanpa risiko kematian yang signifikan karena kegagalan struktural, tidak ada kerusakan signifikan dan bangunan dapat digunakan dan segera berfungsi / dioperasikan kembali.

Kata kunci: Spektrum respons, isolasi dasar, bantalan karet timbal, tingkat kinerja struktural

Received 08 March 2019| Revised 09 May 2019| Accepted 27 September 2019

\section{Introduction}

Indonesia is an area with high earthquake intensity. The earthquake or seismic activities of a region are referred to the types, frequency and size of an earthquake in a period of time. Seismic activity is usually recorded on the land surface whereas building foundations are planted in the ground. Medium earthquake acceleration in long-duration leads to bigger damages than high earthquake acceleration in a short time. Ground motions at a particular site are significantly influenced by the rupture mechanism and slip direction relative to the site and by the permanent ground displacement at the site resulting from tectonic movement [1].

Base-isolated building performance is better compared to non-isolated buildings. The long effective periods and high dampings "standardize" the earthquake attacks while base-isolation simplifies and "standardizes" the building response [2]. The evaluation of an earthquake based on performance has evolved to the point that it is being used effectively in structural designs [3]. Isolated high-story buildings prove that isolation technology has got a big potential in reducing inter-story drift and absolute acceleration of suprastructure and even to high-level buildings [4]. The application of base-isolation reduces the inner forces produced by the elements of the structures such as the columns and beams [5].

There are several buildings which according to the functions require to not have damages from the earthquake in their elements, for example, hospitals that are the most required by earthquake victims. One alternative to prevent these damages is by using base-isolation. The concept is by separating upper structures from the bottom structures which maintains the structures above 
them as one whole unit. Because base-isolation has elastic properties, then the random directions of seismic waves will only affect base-isolation whereas the structures on it vibrate as one whole structural unit [6].

Dynamic analysis for earthquake resistant structural designs is done if a more needed accurate evaluation of the earthquake forces worked on the structure, also to determine the behavior of the structure due to the influence of the earthquake. Dynamic analysis is done in buildings with high-story or irregular structures or configurations [7]. It can be conducted by Response Spectrum Modal Analysis where the maximum response of each kind of vibrations occurred is obtained from the design spectra.

The aim of writing this paper are:

- The structure performance analysis based on existing designs (general hospital in Labura Regency Area) with spectrum response analysis seen based on period, frequency, base shear force, displacement and earthquake force, used the base isolator and without the base isolator.

\section{Literature Review}

\subsection{Modeling Structures}

The schematic structural model is shown in Figure 1 and 2.

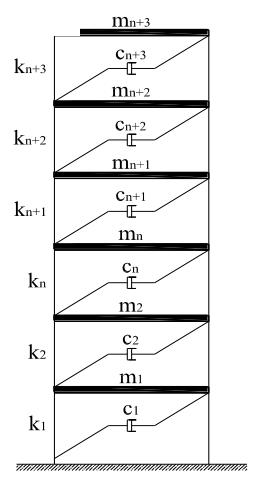

Figure 1. Non-base isolated multi-story building modeling

Generally, multi-degree of freedom (MDOF) of building structures have got a differential equation of motion of the degree of freedom. The equation which occurs due to dynamic forces can be written in a compact matrix as follow [8],

$$
[\mathrm{M}]\{\ddot{\mathrm{Y}}\}+[\mathrm{C}]\{\dot{\mathrm{Y}}\}+[\mathrm{K}]\{\mathrm{Y}\}=\mathrm{P}(\mathrm{t})
$$


with $[\mathrm{M}],[\mathrm{C}]$ and $[\mathrm{K}]$ as mass, dampers and stiffness matrix respectively. $\{\ddot{\mathrm{Y}}\},\{Y$ Y $\}$ and $\{\mathrm{Y}\}$ are acceleration, velocity and deviation vectors. $\mathrm{P}(\mathrm{t})$ is the dynamic loads. If the structures with a high degree of freedom were given ground motions or earthquake force loads, the differential of motion will become [8],

$$
[\mathrm{M}]\{\ddot{\mathrm{Y}}\}+[\mathrm{C}]\{\dot{\mathrm{Y}}\}+[\mathrm{K}]\{\mathrm{Y}\}=-[\mathrm{M}]\{1\} \ddot{u}_{\mathrm{b}}
$$

Either equation 1 or 2 consists of several related equations, they are called as coupled equations or dependent equations.

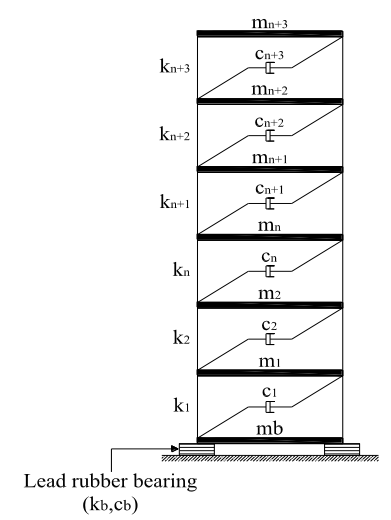

Figure 2. Base isolated multi-story building modeling

The complete mass, stiffness and dumping matrix of the structural system is stated as Mass matrix, $[M]_{(n, n)}$ is stated as [9],

$[M]=\left[\begin{array}{cccccc}m_{1} & & & & & \\ & m_{2} & & & & \\ & & m_{3} & & & \\ & & & \cdots & & \\ & & & & m_{n-1} & \\ & & & & & m_{n}\end{array}\right]$

Stiffness matrix, $[K]_{(n, n)}$ is stated as [9],

$[K]=\left[\begin{array}{cccccc}k_{1}+k_{2} & -k_{2} & & & & \\ -k_{2} & k_{2}+k_{3} & \ldots & & & \\ & \cdots & \ldots & \ldots & & \\ & & \cdots & \ldots & -k_{n-1} & \\ & & & -k_{n-1} & k_{n-1}+k_{n} & -k_{n} \\ & & & & -k_{n} & k_{n}\end{array}\right]$

Dumping matrix, $[C]_{(n, n)}$ is stated as [9]. 


$$
[C]=\left[\begin{array}{cccccc}
c_{1}+c_{2} & -c_{2} & & & & \\
-c_{2} & c_{2}+c_{3} & \ldots & & & \\
& \ldots & \ldots & \ldots & & \\
& & \cdots & \ldots & -c_{n-1} & \\
& & & -c_{n-1} & c_{n-1}+c_{n} & -c_{n} \\
& & & & -c_{n} & c_{n}
\end{array}\right]
$$

\subsection{Lead Rubber Bearing (LRB)}

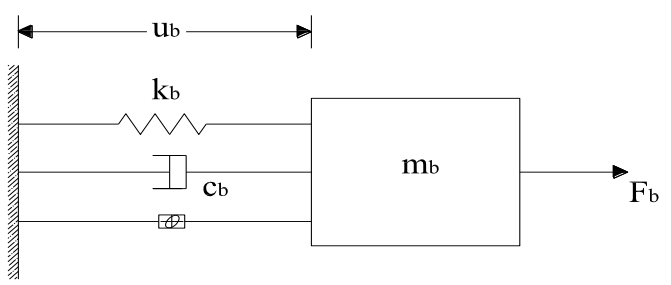

Figure 3. Schematic diagram of Lead Rubber Bearing

The deformation behavior of bearing forces shows non-linear characteristics and the hysterical behavior is characterized by the Wen model. The supporting forces produced by the system is given as [9],

$$
F_{b}=c_{b} \dot{u}_{b}+\alpha_{b} k_{b} u_{b}+f_{z}
$$

where $f_{z}$ is lead core strength (iron), and it is stated as,

$$
f_{z}=\left(1-\alpha_{b}\right) F_{y} q z_{b}
$$

where $\alpha_{b}$ is the parameter and calculated as,

$$
\alpha_{b}=\omega_{b}^{2} M_{t} q / F_{y}
$$

and $F_{y}$ is the yield strength of the isolation.

Isolated system parameters, such as stiffness $\left(k_{b}\right)$, damping $\left(c_{b}\right)$ and yield strength $\left(F_{y}\right)$ are selected based on preferred value of isolation period $\left(T_{b}\right)$, damping ratio $\left(\xi_{b}\right)$ and yield strength coefficient $\left(F_{0}\right)$ which are stated as [9], ,

$$
\begin{gathered}
T_{b}=2 \pi \sqrt{\frac{M_{t}}{\alpha_{b} k_{b}}} \\
\xi_{b}=\frac{c_{b}}{2 M_{t} \omega_{b}} \\
F_{0}=\frac{F_{y}}{W_{t}}
\end{gathered}
$$


The isolated system where effective damping is expressed as a percentage, AASHTO provides conversion of the effective damping value to the effective period of the isolator structure.

Table 1. The damping coefficient of the isolation structure based on AASTHO [6]

\begin{tabular}{cccccccc}
\multicolumn{8}{c}{ Damping (Percentage of critical) } \\
\hline$\xi_{b}$ & $\leq 2$ & 5 & 10 & 20 & 30 & 40 & 50 \\
$B$ & 0,8 & 1 & 1,2 & 1,5 & 1,7 & 1,9 & 2 \\
\hline
\end{tabular}

\section{Methodology}

The methodology used in this study is response-spectrum dynamic analysis by using ETABS v2016 software. The stages in this analysis method are data collection and literature study which involve 3D building structures modelling, calculation and recording of loads working at the structures, calculation of structural response-spectrum by drawing the curve of seismic response spectrum which is followed by inputting the calculation in the modelling and analysis to obtain the value of period, frequency, base friction force, displacement and seismic force. At the last stage, the researched controls the performance of building structure to conclude the analysis result related to the study objectives. The next step is comparing the results of base-isolated and non-base isolated structures in order to get a conclusion for the usage of LRB isolation in observed buildings.

Structural designs of concrete for earthquake according to SNI 1726 - 2012[10] require several stages such as:

- Determining Building Factor

The priority factor is used to enlarge seismic load designs in order to have structures that are able to bear the load in a repetitive and longer period. In other words, structures with low damages level.

- Indonesia seismic zone map SNI $1726-2012$ is stated as :

a. Response spectra map which is set based on Ss (the acceleration of bedrock at a short period of 0.20 seconds) [11].

b. S1 (the acceleration of bedrock at a short period of 1.0 seconds) [11].

- Determining Site Classification

SNI 1726 - 2012 classifies 6 types of soil in order to calculate the potential of amplification.

- Determining Site Coefficient, $F_{a}$ and $F_{v}$

The site coefficient is an amplification factor to soil response parameter and the function of its characteristics. $F_{a}$ is the amplification acceleration factor for a short period while $F_{v}$ is the amplification velocity for a long period. 
- Determining Seismic Design Category

- Making Response Spectrum Design

The response spectrum in Labura Regence with soil conditions based on Indonesia spectra (date 25 Agustus 2018) [11] can be seen as follow.

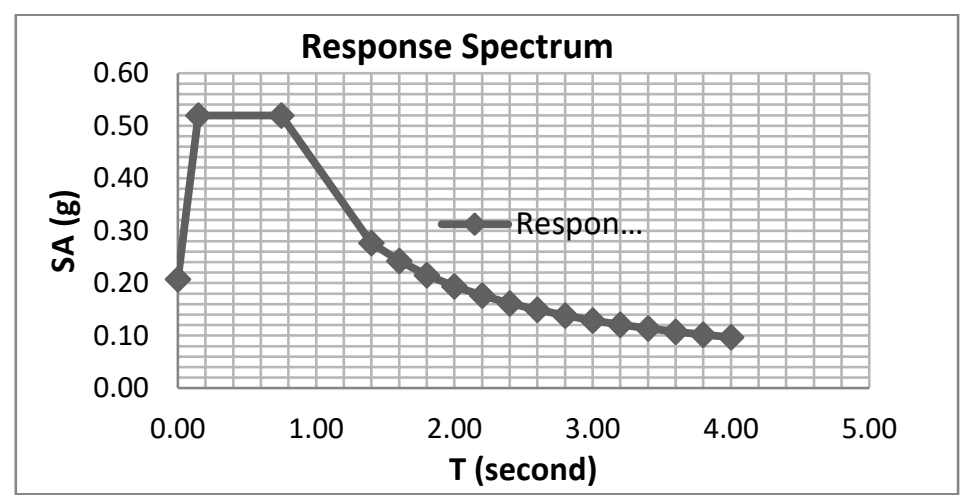

Figure 4. Response spectrum graph [12].

\section{Results And Discussion}

\subsection{General Data of the Building}

Building configuration $=$ Uniform; Total story $=6$ levels; Building height $: 25.2 \mathrm{~m}$; Building length : $50.40 \mathrm{~m}$; Building width : $21.60 \mathrm{~m}$; Type of soil = Medium land. Building Element Dimension : Floor plate thickness $=120 \mathrm{~mm}$; Primary beam $=300 \mathrm{~mm}$ x $600 \mathrm{~mm}$; Secondary beam $=200 \mathrm{~mm} \times 400 \mathrm{~mm}$; Primary column : $700 \mathrm{~mm} \times 700 \mathrm{~mm}$; Concrete grade $\left(\mathrm{f}^{\prime} \mathrm{c}\right)=30$ Mpa; Steel grade (fy) $400 \mathrm{Mpa}$ (for bar diameter $\geq 12 \mathrm{~mm}$ ); $240 \mathrm{Mpa}$ (for bar diameter $<12$ $\mathrm{mm}$ ); Building function $=$ Hospital.

\subsection{Load Analysis}

Dead Load $=$ In accordance with Indonesian SNI-1727-2013 regulations[13]; Live Load $=250$ $\mathrm{kg} / \mathrm{m}^{2}$; Seismic Load : Building risk category = Risk category IV; Building primary factor to earthquake $(\mathrm{Ie})=1.50$; Response spectra value $:$ The determination of seismic response spectra parameter in a short period or 1-second period can be seen in the seismic map provided in Puskim Website PU. The reading of response spectra parameter give the values $S_{1}=0.337 \mathrm{~g}$; $\mathrm{S}_{\mathrm{S}}=0.585 \mathrm{~g}$; site coefficient $\mathrm{Fa}=1.332 ; \mathrm{Fv}=1.726$; Acceleration response spectrum parameter : desain : $S_{D S}=0,5195 ; S_{D 1}=0,3878 ;$ Seismic Design Category $=$ D Category.

\subsection{Non-base Isolated Structures Modelling}

After all loads, such as dead, live and seismic loads, are calculated, the building structures are then designed using ETABS v2016 software. This aims to get the total building and axial loads 
owned by one column point in the building. This is necessary for isolation dimension design. The modeling with no base-isolation can be seen in Figure 5 below:

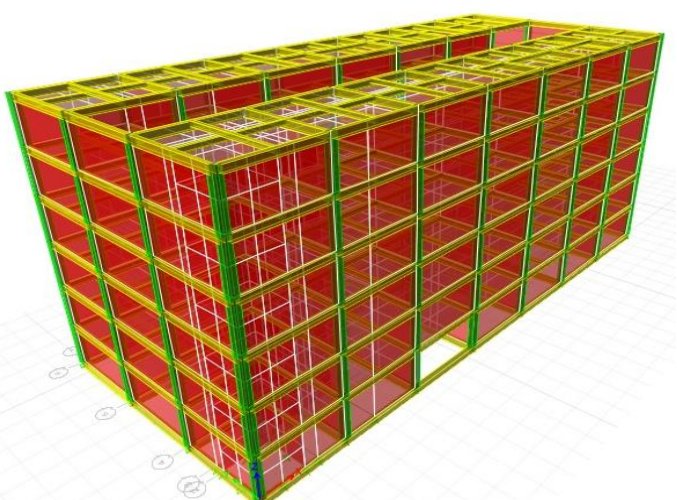

Figure 5. Fixed Base Structure Modelling

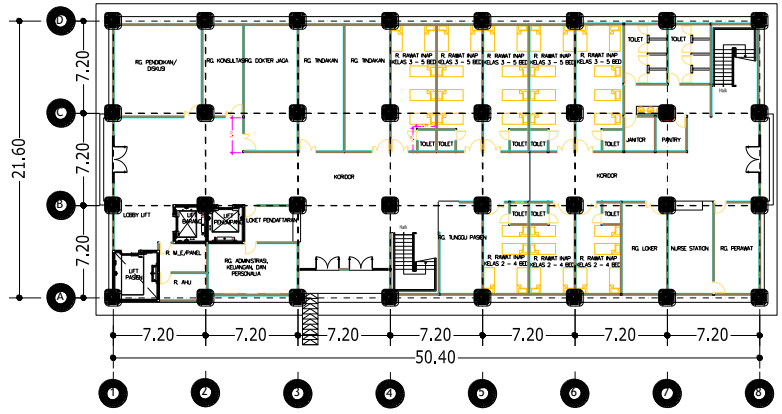

Figure 6. Building Plan

\subsection{Lead Rubber Bearing (LRB) Base Isolation Dimension Design}

Structure isolation analysis is started with fixed base analysis to get the reaction and period of structure in pinched condition. The stages for LRB base-isolation dimension design are as follow:

- Calculate building weight. From the structure analysis, $\mathrm{Wt}=56,266.96 \mathrm{kN}$ is obtained

- Determine the design period $\left(\mathrm{T}_{\mathrm{D}}\right)$ for LRB dimension based on SNI 1726 - 2012[10] clause 12.4. $\mathrm{T}_{\mathrm{D}}=3 \times \mathrm{T}$ fixed base fundamental $=3 \times 1.372=4.11$ seconds.

- Calculate the behavior of the designed isolation by early specification assumption based on Brosur Base Isolation used. For this research, the brosur used was obtained from FIP INDUSTRIALE [14].

From the brosur used, LRB dimension was calculated and therefore the following types are taken:

a. LRB-S 600/102-120 (Interior), with data as follow (data was taken from the factory with $\pm 100 \mathrm{~mm}$ displacement): $\mathrm{V}=4830 \mathrm{kN} ; \mathrm{k}_{\mathrm{H}}=2.49 \mathrm{kN} / \mathrm{mm} ; \mathrm{D}=600 \mathrm{~mm} ; \mathrm{H}=240 \mathrm{~mm} ; \mathrm{Te}=$ $102 \mathrm{~mm}$.

b. LRB-SN 600/102-120 (Exterior), with data as follow (data was taken from the factory with $\pm 100 \mathrm{~mm}$ displacement): $\mathrm{V}=7250 \mathrm{kN} ; \mathrm{k}_{\mathrm{H}}=3.02 \mathrm{kN} / \mathrm{mm} ; \mathrm{D}=600 \mathrm{~mm} ; \mathrm{H}=240 \mathrm{~mm} ; \mathrm{T}_{\mathrm{e}}=$ $102 \mathrm{~mm}$.

\subsection{Base-Isolated Building Design}

After the suitable base isolation dimension for the building was obtained, the building was modeled using the base isolation as shown in Figure 7: 


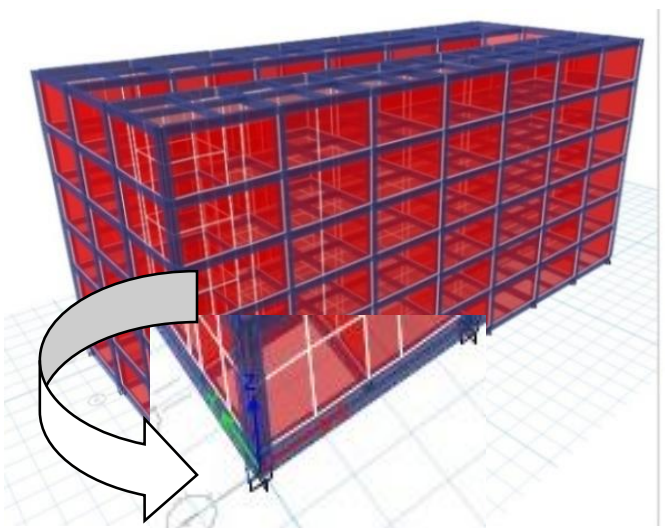

Figure 7. Base-isolated structure modeling

\subsection{Structural Periode and Frequency}

Table 2. Structural periode and Frequency Comparison [12]

\begin{tabular}{ccccc}
\hline \multirow{2}{*}{ Mode } & \multicolumn{2}{c}{ Periode } & \multicolumn{2}{c}{ Frequency } \\
\cline { 2 - 5 } & $\begin{array}{c}\text { Without } \\
\text { Bearing (sec) }\end{array}$ & $\begin{array}{c}\text { With Bearing } \\
(\mathbf{s e c})\end{array}$ & $\begin{array}{c}\text { Without Bearing } \\
(\mathbf{s e c})\end{array}$ & $\begin{array}{c}\text { With Bearing } \\
(\mathbf{s e c})\end{array}$ \\
\hline 1 & 1,372 & 2,189 & 0,729 & 0,457 \\
2 & 0,729 & 1,664 & 1,372 & 0,601 \\
3 & 0,631 & 1,486 & 1,585 & 0,673 \\
4 & 0,437 & 0,576 & 2,288 & 1,736 \\
5 & 0,253 & 0,348 & 3,953 & 2,874 \\
6 & 0,18 & 0,335 & 5,556 & 2,985 \\
7 & 0,173 & 0,313 & 5,780 & 3,195 \\
8 & 0,146 & 0,266 & 6,849 & 3,759 \\
9 & 0,138 & 0,249 & 7,246 & 4,016 \\
10 & 0,083 & 0,232 & 12,048 & 4,310 \\
11 & 0,064 & 0,183 & 15,625 & 5,464 \\
12 & 0,057 & 0,168 & 17,544 & 5,952 \\
\hline
\end{tabular}

Based on Table 2 it can be seen that the structure period value increases with the use of LRB on structural elements, and decreases in the frequency value of the structure. Increasing the period of the structure causes the earthquake force to work on the building to be smaller. By using a base isolator the period increases when it happens of an earthquake the structure to reduce base shear as shown in Figure 7 [8].

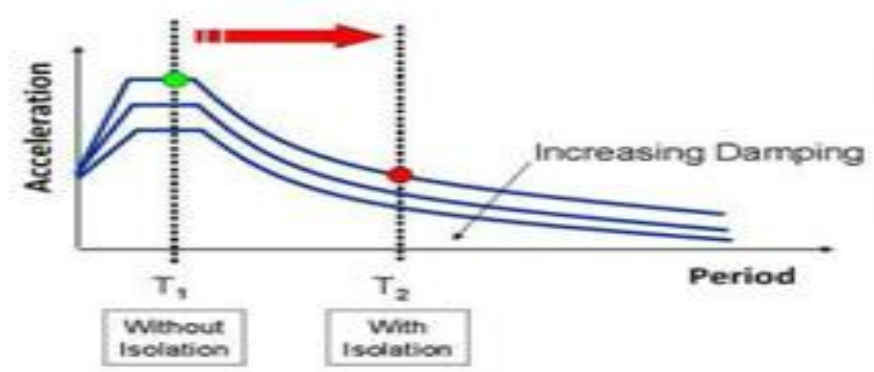

Figure 7. Spectra Acceleration Response as a Function of Damping 


\subsection{Comparison of Displacement Structural}

a. Displacement at $\mathrm{X}$ direction

By using a base isolator 6th floor displacement increased from $19.435 \mathrm{~mm}$ to $53.964 \mathrm{~mm}$ or increased by $34,529 \mathrm{~mm}$. The increase in direction displacement of $\mathrm{x}$ can be seen in Table 3 and can be shown in Figures 8 and 9.

Table 3. Comparison of the Direction Displacement of $\mathrm{X}\left(\delta_{x}\right)$ [12]

\begin{tabular}{lclc}
\hline Floor & $\begin{array}{c}\text { Without LRB } \\
(\mathbf{m m})\end{array}$ & Floor & $\begin{array}{c}\text { With } \\
\text { LRB } \\
(\mathbf{m m})\end{array}$ \\
\hline Floor -6 & 19,435 & Floor -6 & 53,964 \\
Floor -5 & 16,259 & Floor -5 & 48,676 \\
Floor - 5 & 12,339 & Floor -4 & 41,316 \\
Floor - 3 & 7,953 & Floor -3 & 32,847 \\
Floor - 2 & 3,52 & Floor -2 & 23,484 \\
Floor -1 & 0,0001097 & Floor -1 & 13,442 \\
\hline
\end{tabular}

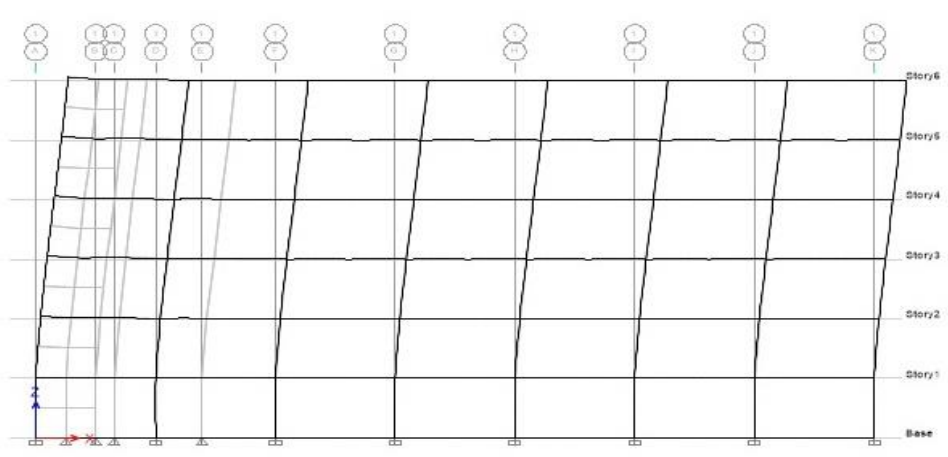

Figure 8. Displacement at $X$ direction without LRB

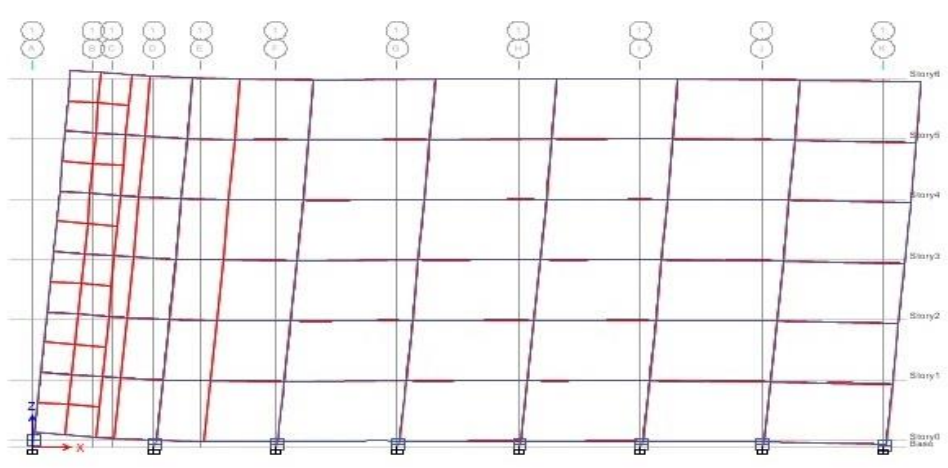

Figure 9. Displacement at X direction with LRB

b. Displacement at $\mathrm{Y}$ direction

Displacement at $\mathrm{Y}$ direction is very small, where on the 3rd floor without Base isolator displacement of $1,092 \mathrm{~mm}$. And the use of base isolators increases to 3,288 $\mathrm{mm}$ or increases to 2,196 mm. The increase direction displacement of y can be seen in Table 4 and can be shown in Figures 10 and 11. 
Table 4. Comparison of the Direction Displacement of $Y\left(\delta_{\mathrm{y}}\right)[12]$

\begin{tabular}{lclc}
\hline Floor & $\begin{array}{c}\text { Without } \\
\text { LRB } \\
(\mathbf{m m})\end{array}$ & Floor & $\begin{array}{c}\text { With } \\
\text { LRB } \\
(\mathbf{m m})\end{array}$ \\
\hline Floor -6 & 1,956 & Floor -6 & 5,908 \\
Floor -5 & 1,846 & Floor -5 & 5,038 \\
Floor -4 & 1,547 & Floor -4 & 4,237 \\
Floor -3 & 1,092 & Floor -3 & 3,288 \\
Floor -2 & 0,524 & Floor -2 & 2,244 \\
Floor -1 & 0,071 & Floor -1 & 1,133 \\
\hline
\end{tabular}

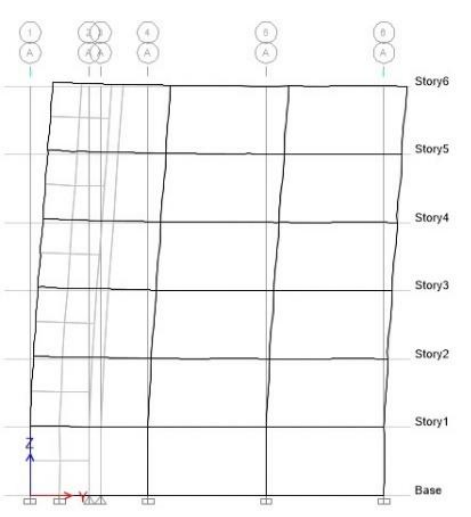

Figure 10. Displacement at $Y$ direction without LRB

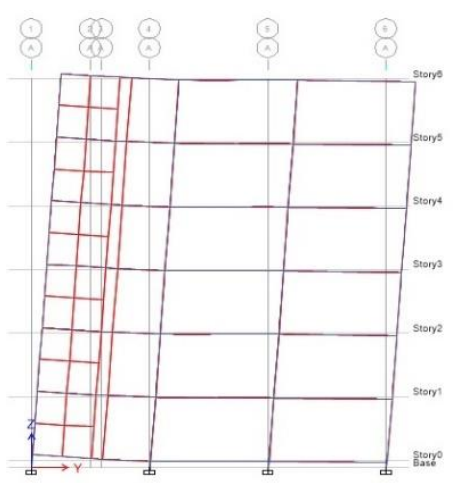

Figure 11. Displacement at $Y$ direction with LRB

\subsection{Structural Base Shear Comparison}

By using a base isolator the base shear direction of $\mathrm{x}$ decreases from $93.96 \mathrm{kN}$ to $39.92 \mathrm{kN}$. The base shear values can be seen in Table 5 .

Table 5. The comparison of Base Shear [12]

\begin{tabular}{ccc}
\hline Directions & $\begin{array}{c}\text { Without LRB } \\
(\mathbf{k N})\end{array}$ & $\begin{array}{c}\text { With LRB } \\
(\mathbf{k N})\end{array}$ \\
\hline $\mathrm{X}$ & 93,96 & 39,92 \\
$\mathrm{Y}$ & 76,99 & 13,30 \\
\hline
\end{tabular}




\subsection{Structural Seismic Force Comparison}

Structural Seismic Force that reviewed is the direction of $\mathrm{x}$ and direction of $\mathrm{y}$. From the results of the analysis by the ETABS program, the value direction seismic of $\mathrm{x}$ is obtained in Table 6 and the direction seismic of y in Table 7.

Table 6. The comparison of the structural seismic force X direction [12]

\begin{tabular}{lcc}
\hline & & \\
Floor & Without LRB $(\mathrm{kN})$ & With LRB $(\mathrm{kN})$ \\
& & \\
\hline Floor -1 & 0,96 & 0,41 \\
Floor -2 & 4,40 & 1,87 \\
Floor -3 & 9,94 & 4,22 \\
Floor -4 & 17,65 & 7,50 \\
Floor -5 & 27,58 & 11,72 \\
Floor -6 & 33,42 & 14,20 \\
\hline
\end{tabular}

For the next of structural seismic force in the direction of $\mathrm{x}$ can be seen in Figures $12 \mathrm{a}$ and $12 \mathrm{~b}$

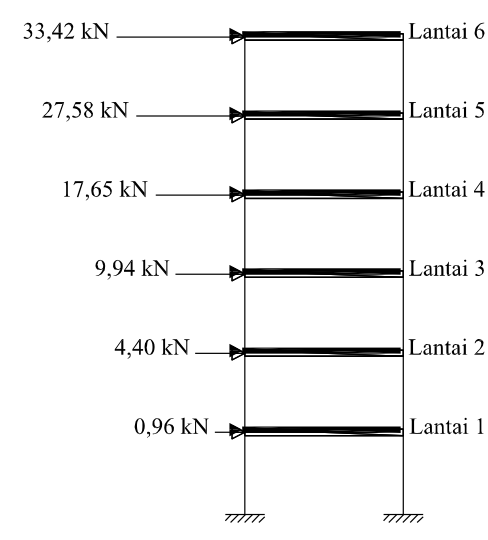

Figure 12a. Seismic force without LRB

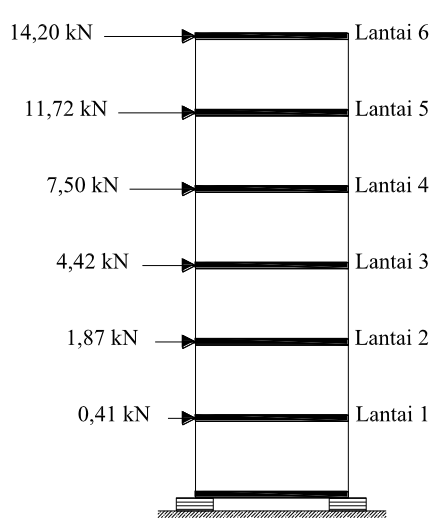

Figure 12b. The seismic force with LRB

Table 7. The comparison of structural seismic force Y direction [12]

\begin{tabular}{ccc} 
Floor & $\begin{array}{c}\text { Without LRB } \\
(\mathrm{kN})\end{array}$ & With LRB $(\mathrm{kN})$ \\
\hline Floor -1 & 0,79 & 0,14 \\
Floor -2 & 3,61 & 0,62 \\
Floor -3 & 8,14 & 1,41 \\
Floor -4 & 14,47 & 2,50 \\
Floor -5 & 22,60 & 3,90 \\
Floor -6 & 27,38 & 4,73 \\
\hline
\end{tabular}


For the next of structural seismic force in the direction of $y$ can be seen in Figures 13a and 13b

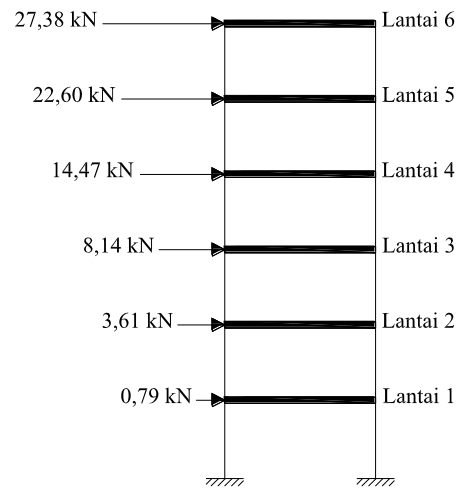

Figure 13a. Seismic force without LRB

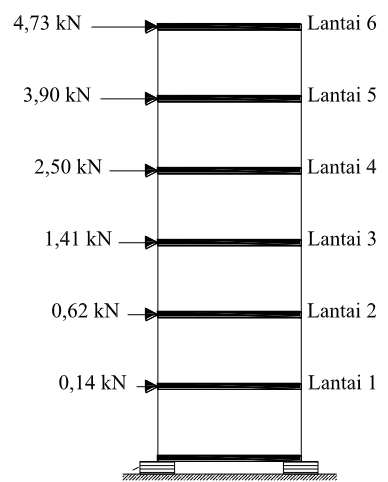

Figure 13b. Seismic force with LRB

Seismic forces that occur in structures using base isolators can reduce the average of $57.51 \%$ in the direction of $\mathrm{x}$ and $82.73 \%$ in the direction $\mathrm{y}$

\subsection{Structural Performance Level (ATC-40)}

a. X Direction Performance Evaluation

With the limit of roof drift ratio evaluated with various response spectrum analysis of the building without use LRB, with maximum total drift and inelastic drift, hence:

Table 8. The structural performance level of $\mathrm{X}$ direction

\begin{tabular}{|c|l|}
\hline $\mathrm{D}_{\mathrm{t}}(\mathrm{m})$ & 0,0194 \\
\hline $\mathrm{D}_{1}(\mathrm{~m})$ & 0,0000 \\
\hline $\mathrm{H}_{\mathrm{t}}(\mathrm{m})$ & 25,2 \\
\hline Maksimum toral drift $(\mathrm{Dt} / \mathrm{ht})$ & 0,00077 \\
\hline Level of performance & Immediate Occupancy \\
\hline $\begin{array}{c}\text { Maximum total inelastic } \\
\text { drift }\left(D_{\mathrm{t}}-D_{1}\right) h_{\mathrm{t}}{ }^{3}\end{array}$ & 0,00077 \\
\hline Level of performance & Immediate Occupancy \\
\hline
\end{tabular}

Note:

$\mathrm{D}_{\mathrm{t}} \quad=$ roof displacement (top)

$\mathrm{D}_{1} \quad=1$ st floor displacement (floor above lateral clamping)

According to ATC-40, the drift ratio limit is as follows: 
Table 9. Limitation of Roof Drift Ratio According to ATC-40 [15]

\begin{tabular}{lcccc}
\hline \multicolumn{1}{c}{ Parameter } & IO & Demage Control & LS & $\begin{array}{c}\text { Structural } \\
\text { Stability }\end{array}$ \\
\hline $\begin{array}{l}\text { Maximum Total } \\
\text { Drift }\end{array}$ & 0,01 & 0,01 s.d 0,02 & 0,02 & $0,33 \frac{v i}{p i}$ \\
$\begin{array}{l}\text { Maximum Total } \\
\text { Inelastik Drift }\end{array}$ & 0,005 & 0,005 s.d 0,015 & No Limit & No Limit \\
\hline
\end{tabular}

b. Y Direction Performance Evaluation

With the limit of roof drift ratio evaluated with various response spectrum analysis of the building without use LRB, with maximum total drift and inelastic drift, hence:

Table 10. The structural performance level of $\mathrm{Y}$ direction

\begin{tabular}{cl}
\hline $\mathrm{D}_{\mathrm{t}}(\mathrm{m})$ & 0,001956 \\
$\mathrm{D}_{1}(\mathrm{~m})$ & 0,0000 \\
$\mathrm{H}_{\mathrm{t}}(\mathrm{m})$ & 25,2 \\
Maksimum toral drift $(\mathrm{Dt} / \mathrm{ht})$ & $7,76 \mathrm{E}-05$ \\
Level of performance & Immediate Occupancy \\
Maximum total inelastic & \\
drift $\left\{\left(D_{\mathrm{t}}-D_{1}\right) h_{\mathrm{t}}\right\}$ & $7,76 \mathrm{E}-05$ \\
& \\
& Immediate Occupancy \\
\hline
\end{tabular}

The evaluation result of structural performance level is in accordance with Applied Technology Council 40[15] as shown in Table 8 and 10. The maximum total drift and inelastic drifts values at $\mathrm{x}$ and $\mathrm{y}$ direction are categorized into Immediate Occupancy (IO). This means that the building structures are safe with no significant risk of fatalities due to structural failures, there are no significant damages and the building can be used and functioned/operated again immediately.

\section{Conclusion And Suggestion}

\subsection{Conclusion}

From the result design and analysis in the previous chapter, they can be concluded as follow:

1. The comparisons of period, frequency, base friction force, displacement and seismic force in the building observed with and without LRB base isolation are :

- The application of base isolation is able to build up the period of the structure, therefore, the maximum acceleration from earthquake can be reduced at certain period. There is an average increase by $48.21 \%$ of the structural period compared to non-isolated base, and the frequency that occurs in structures using base isolators is smaller than without base isolators. 
- By using earthquake damper system such as lead rubber bearing, the base shear force obtained from response spectrum gave smaller value compared to the structure without dampers.

- The observed building structures with base isolation have got higher displacement than non-base isolated structures. In this case, the elevated displacement in the building averagely is $27.14 \%$ and $\mathrm{X}$ and $2.74 \%$ at $\mathrm{Y}$ directions.

- The seismic force in the base-isolated structure is able to reduce the force averagely by $85.85 \%$ at $X$ and $48.15 \%$ at $\mathrm{Y}$ directions.

2. The structural performance analysis result shows that the structures of General Hospital in Labuhan Batu Utara Regency is categorized into Immediate Occupancy (IO) in which the building structures are safe with no significant risk of fatalities due to structural failures, there are no any significant damages and the building can be used and functioned/operated again immediately.

\section{REFERENCE}

[1] M.K. Sharbatar, S.R. Hoseini Vaez, G.G. Amiri, and H. Naderpour, "Seismic Response of Base-Isolated Struktur with LRB and FPS under near Fault Ground Motion," in Proceeding Engineering 14 (2011), pp. 3245-3251, 2011.

[2] M. K. Sharbatdar, S. R. H. Vaez, G. G. Amiri, and H. Naderpour, "Seismic Response of Base-Isolated Structures with LRB and FPS under near Fault Ground Motions," Procedia Eng., vol. 14, pp. 3245-3251, 2011.

[3] S. Moretti, A. Trozzo, V. Terzic, G. P. Cimellaro, and S. Mahin 2014. "Utilizing base isolation system to increase eatrhquake resiliency of healthcare and school buildings," in Procedia Economics and Finance 18 ( 2014 ), pp. 969 - 976, 2014.

[4] C. Ma, Y. Zhang, Y. Zhao, P. Tan and F. Zhou, "Stochastic Seismic Response Analysis of Base-Isolated High-rise Buildings", in Procedia Engineering 14 (2011), pp. 2468-2474, 2011.

[5] T. Respons, S. Gedung, and H. Ibis, "Pengaruh penggunaan," vol. 8, no. 1, pp. 45-60, 2012.

[6] W. Andrian, Faimun, and E. Wahyuni, "Evaluasi Kinerja Gedung Menggunakan Base Isolation Tipe High Damping Rubber Bearing (HDRB) Pada Modifikasi Gedung J-Tos Jogjakarta Dengan Perencanaan Analisis Pushover,” Journal Teknik Vol. 6, no. 2, pp. 2337-3520, 2017

[7] E. Purnomo, E. Purwanto, and A. Supriyadi, "ANALISIS DINAMIK RESPON SPEKTRUM MENGGUNAKAN SOFTWARE ETABS ( STUDI KASUS : BANGUNAN HOTEL DI SEMARANG ),” pp. 569-576, 2014.

[8] A.K. Chopra, Dynamics of Structures: Theory and Applications to Earthquake Engineering, 4rd ed., Pearson Education, Inc, 2012

[9] M.K. Shrimali, S.D. Bharti, and S.M. Dumne, "Seismic response analysis of coupled building involving MR damper and elastomeric base isolation," Ain Shams Engineering Journal (2015), ), pp. 457-470, 2015.

[10]BSN, "Tata Cara Perencanaan Ketahanan Gempa untuk Struktur Bangunan dan Non Gedung SNI 1726-2012," Badan Standardisasi Nasional, ICS 91.120.25;91.080.01 [Online]. Available: http://www.bsn.go.id. 
[11][Online]. "Peta Wilayah Gempa di Indonesia untuk Ss dan untuk $S_{I}$ untuk wilayah Kab. Labura," Available: Http://puskim.pu.go.id/aplikasi/desain_spektra_Indonesia, [Accessed: August. 25, 2018].

[12]M. Irwansyah, "Analisis Kinerja Struktur Pada Gedung Rumah Sakit Yang Menggunakan Base Isolator Dengan Modal Analysis (Studi Kasus: Gedung Rumah Sakit Umum Daerah Kab. Labuhan Batu Utara," M.T. thesis, Univ. of Sumatera Utara,

[13] BSN, "Peraturan Pembebanan Indonesia Untuk Gedung Dan Bangunan Lain SNI 17272013," Badan Standardisasi Nasional, ICS 91.080.01 [Online]. Available: http://www.bsn.go.id.

[14] Anonymous. Devices With Ce Marking (CE), Fip Industriale leading technologies, Italy. Brosur Lead Rubber Bearing (LRB), 1992

[15] ATC-40 (Ed.), Seismic Evaluation and Retrofit of Concreate Building, Seismic Safety Commision State of California, Report No. SSC 96-01, 1996. 